\title{
Does The Use Of Derivatives Increase Bank Efficiency? Evidence From Latin American Banks
}

\author{
Andres Rivas, (Email: arivas@tamiu.edu), Texas A\&M International University, \\ Teofilo Ozuna, University of Texas-Pan American \\ Felice Policastro, Gardner-Webb University
}

\begin{abstract}
This study investigates whether the use of derivatives by banks in Latin America affect their efficiency. Overall, and in line with theory, the results indicate that the use of derivatives increases the efficiency of Latin American banks. Additionally, we find that as Latin American banks get larger their efficiency levels increases. Lastly, the results show that regulatory and institutional constraints negatively affect the efficiency of Latin American banks.
\end{abstract}

\section{INTRODUCTION}

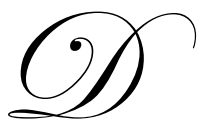

uring the 1990s, Latin American countries implemented policies aimed at liberalizing their financial markets. Latin American countries deregulated the domestic financial and banking industries, removed controls on international capital flows, and promoted development of their domestic stock market. These countries implemented financial liberalization policies and programs in order to stimulate domestic savings and growth. Through financial liberalization, they also attempted to reduce the direct intervention of the state in the economy and improve their financial infrastructure.

The implementation of such policies has led to an increase in capital flows to Latin America, an increase in the number of foreign banks, and the opening of stock markets in the region. The recent financial liberalization policies have also changed the business environment of the banking industry considerably and thereby increasing the risk they faced. Latin American banks were directly affected because they were direct targets of the liberalization process (Fischer et al. 1997). The elimination of deposit and lending rate controls resulted in interest rate uncertainty, and this led to increases in the level and volatility of deposit and lending rates. With liberation of interest rates, increases in deposit rates practically forced banks to seek lending at higher rates in projects that were riskier. Finally, volatility in interest rates increased both financing costs and failure risk of bank non-financial costumers deteriorating the quality of bank assets accordingly (Fischer et al. 1997).

After deregulation of the banking industry Latin American banks provided credit, without appropriate credit risk analyses (Hughes and McDonald, 2002). Latin American banks began to implement internal risk management programs in order to cope with the risk brought by financial liberalization. Latin American banks began to use offshore derivatives markets, and many cross-market links were established with exchanges outside the region. Additionally, various Latin American countries opened securities exchanges that trade derivatives contracts, and overthe-counter (OTC) derivatives markets are emerging domestically (Hughes and McDonald, 2002). By 2001, the notional value of derivatives contracted by banks in Brazil, Chile, and Mexico amounted to about US $\$ 865,025$ million and of this total Brazil held the largest value (US\$829,210 million) followed by Chile (US\$34,971 million) and Mexico (US\$844 million) (Bankscope).

Surprisingly, not much is known regarding the use of derivatives by banks in Brazil, Chile, and Mexico or the rest of Latin America. Given the growing importance on the use of derivatives by banks in Brazil, Chile, and 
Mexico, and the goals that such as financial liberalization process is pursuing, it is imperative to know the impact that the use of financial instruments such as derivatives has had on Latin American banks. Thus, the questions that remain unanswered are: Does derivatives usage increase or decrease the efficiency of Latin American banks? Is the efficiency effect of derivatives similar across different Latin American countries? The answers to these questions are important to bank managers and shareholders concerned with improved profitability and service. They are also important to bank policy-makers and regulators who want a safe and sound banking system capable of avoiding the banking crisis Latin America suffered over the last two decades.

The purpose of this study is to examine whether the use of derivatives affects the efficiency of banks in Brazil, Chile and Mexico. The study contributes to the literature in that it is the first to provide empirical evidence regarding the effect of derivatives on bank efficiency. No other study has examined this issue in developed or emerging countries. Overall, the results indicate that the use of derivatives increases the efficiency of Latin American banks. The results show that the size of portfolio loans, equity ratio, and total assets have a positive effect on the efficiency of Latin American banks. Lastly, the results indicate that a country's economic, regulatory and institutional constraints can negatively affect the efficiency of Latin American banks.

In the next section, we present a background on the use of derivatives. Section 3 presents a theory regarding derivative usage and bank efficiency. Section 4 presents the model used to measure the effect of derivatives on efficiency. In section 5, the data and its sources as well as its summary statistics is presented. Section 6 presents the empirical results. Lastly, section 7 provides concluding comments and implications regarding the study.

\section{DERIVATIVE USAGE BACKGROUND}

Studies regarding the increasingly important role derivatives play in the bank sector can be classified into two broad groups. The first group of studies examines the use of derivatives by commercial banks. For instance, Gunther and Siems (1995) find that banks use derivatives to hedge rather than to speculate. Carter and Sinkey (1998), Gunther and Siems (1996) and Sinkey and Carter (2000) find that increases in the bank's use of interest-rate derivatives correspond to greater interest rate risk exposure. Whidbee and Wohar (1999) find that the corporate governance and ownership-structure of banks influences the bank's use of derivatives. Brewer et al. (2000) find that banks that use derivatives experience greater growth in lending. Lastly, Shyu and Reichert (2002) find that international dealer banks' derivatives activities are directly related to bank size.

The second group of studies investigates the effect of the use of derivatives on different types of bank risks (e.g., interest-rate, exchange rate, market, and unsystematic). For example, Shanker (1996) finds that the use of swaps, future, and options reduce interest-rate risk. Hirtle (1997) finds that the use of interest-rate derivatives increases the interest-rate exposure of bank holding companies (BHC). Choi and Elyasiani (1997) find that options are positively related to both interest-rate and currency risk, while currency swaps reduce exchange rate risk. Chaudhry and Reichert (1999) and Chaudhry et al. (2000) find that the use of options tends to increase all types of risk, while interest rate and currency swaps significantly reduce bank risk. Lastly, Reichert and Shyu (2003) find that the use of options increases an international bank's interest-rate risk exposure.

\section{DERIVATIVES USAGE AND BANKS EFFICIENCY}

Finance theory suggests that capital market imperfections create incentives for firms (including banks) to use derivatives for hedging purposes. Several authors, such as Smith and Stulz (1985), Nance et al. (1993) and Fok et al. (1997) argue that there are three major benefits from using derivatives: reduced taxes under a progressive tax schedule, reduced expected cost of financial distress, and reduced agency cost problems.

Smith and Stulz (1985) argue that if taxes are a convex function of earnings, it will be optimal for firms to use derivative for hedging purposes. Hedging can reduce the present value of the expected tax liability by smoothing the profit stream and reducing the likelihood that the firm will pay higher taxes in one period while having to forego (or delay) the benefits of a tax shield in another period. Froot et al. (1993) argue that the logic is 
straightforward-convexity implies that a more volatile earnings streams lead to higher expected taxes than a less volatile earning stream.

Smith and Stulz (1985) and Mayer and Smith (1982) develop financial distress arguments for derivative usage for hedging purposes and claim that hedging reduces the volatility of the firm's value, by reducing the likelihood of costly financial distress and thus increasing the expected value of the firm. The greater the probability of distress or distress-induced costs, the greater the firm's benefits from hedging through the reduction in these expected cost. Additionally, Sinkey and Carter (2000) contend that the larger the debt relative to value, the higher the probability of bankruptcy, and the higher the likelihood that a bank will use derivatives to hedge.

Derivative use for hedging purposes can reduce agency costs in two ways. (1) it can be a cost efficient way of aligning the interests of managers and stockholders, and (2) it can align the interests of bondholders and shareholders. Because of the potential for wealth transfers from bondholders to shareholders, firms must conciliate bondholders either through bond covenants or hedging (Myers and Smith, 1987; Nance et al. 1993). Since banks can use derivatives to hedge, they can reduce the volatility of their cash flow and pay out greater levels of income as dividends, ensuring their bondholders that sufficient cash flow is available for debt payment. Additionally, the use of derivatives for hedging helps alleviate the incentive and monitoring problems caused by managerial risk aversion (Carter and Sinkey 1998).

Merton (1995) argues that financial innovations (derivatives) can improve economic performance by lowering transaction costs or increasing liquidity, and by reducing agency costs. The use of derivatives allows banks to improve their capital buffers that absorb risk and this result in lower costs and greater value (Mayers and Smith, 1982; Smith and Stulz, 1985; Merton, 1992). The proper use of derivatives can lower banks financing costs, and consequently improve their efficiency.

\section{MODEL SPECIFICATION}

To determine whether derivatives usage increases bank efficiency, we employed a two-stage approach. The objective of the first stage is to measure the efficiency of Latin American banks. To do this we use the data envelopment analysis employed by Taylor et al. (1997). The objective of the second stage is to examine the sensitivity of the efficiency scores of Latin American banks to the use of derivatives. In this step, we use a regression analysis to determine this sensitivity.

\section{Measuring Banking Efficiency Using DEA}

A large number of studies have measured the efficiency of banks using data envelopment analysis (DEA) (Berger and Humphrey, 1992; Berger et al. 1993; Berger and Humphrey, 1997; McAllister and McManus, 1993; Mester, 1993; Favero and Papi, 1995; Canhoto and Dermine 2003). DEA is a non-parametric linear programming method utilized to constructs production frontiers and measures efficiency relative to the constructed frontier (Coelli et al., 1998). In this study, we use the DEA model developed by Taylor et al. (1997) who used it to measure the efficiency of banks in Mexico. Our use of the DEA approach to measure the efficiency of Latin American Banks is justified in that data regarding the price of inputs and outputs in the Latin American banking sector is practically nonexistent.

Taylor et al. (1997) used an intermediation-input-oriented model $^{1}$ in which the output vector represents TOTAL INCOME while the input vector includes TOTAL DEPOSITS and TOTAL NON-INTEREST EXPENSES. ${ }^{2}$ This model is especially suited for the highly aggregated bank data that is readily available in Brazil, Chile, and Mexico.

\footnotetext{
${ }^{1}$ The difference between the production and intermediation approaches is discussed in Clark (1988).

${ }^{2}$ Elyasiani and Mehdian(1990), Berger and Humphrey (1997) used the same definition of inputs and outputs.
} 
Following Talyor et al. (1997), we used the VRS-DEA model, which is defined as follows:

$$
\begin{aligned}
& \min _{\theta, \lambda} \theta, \text { subject to } \\
& -\mathrm{y}_{\mathrm{i}}+\mathrm{Y} \lambda \geq 0, \\
& \theta \mathrm{x}_{\mathrm{i}}-X \lambda \geq 0
\end{aligned}
$$

\section{$N 1^{\prime} \lambda=1 ; \lambda \geq 0$, where $\mathrm{N} 1$ is an $\mathrm{Nx} 1$ vector of ones.}

The vector of $\theta$ contains the efficiency scores for each of the banks in our sample. It is this efficiency score that will be used in the second stage of our analysis.

\section{Measuring The Effects Of Derivatives Usage On Banking Efficiency}

To measure the effects of derivatives usage on banking efficiency, we regress the efficiency scores obtained in the first stage on a variable representing derivatives usage and control variables that have been documented to affect efficiency scores. As such, we specify the regression equation as:

$$
\begin{aligned}
\text { EFFICIENCY }= & \alpha_{0}+\alpha_{1} \text { DERIVATIVES }_{i}+\alpha_{2} \text { LOANS }_{i}+ \\
& \alpha_{3} \text { EQUITY RATIO }_{i}+\alpha_{4} \text { TOTAL ASSETS }_{i}+ \\
& \alpha_{5} \text { ECON FREE }_{i}+\varepsilon_{i}
\end{aligned}
$$

In this regression, EFFICIENCY represents the efficiency scores of Latin American banks obtained from the DEA model of the first stage. The $\alpha$ 's are parameters that will be estimated and $\varepsilon_{i}$ is a normally distributed disturbance term with mean 0 and variance $\sigma$.

In this study, we are concern about the use derivatives rather than the extent of their value. Therefore, we use the dummy variable DERIVATIVES, which take the value of 1 if a bank uses derivatives, 0 otherwise. If Latin American banks are using derivatives to hedge, a positive relation between DERIVATIVES usage and the efficiency score of Latin American banks is expected. Note that if the coefficient for DERIVATIVES is insignificant, it indicates that derivatives usage does not affect the efficiency of Latin American banks.

The variable LOANS measures the loans portfolio of the bank. McAllister and McManus (1993) argued that the size of the loans portfolio, which is a proxy for asset diversification, plays an important role in determining risk and hence, on average banks with small loan portfolios are required to maintain much higher capital levels than are banks with large portfolios, and this reduces the banks' ability to perform efficiently. Thus, we expect a positive relation between the size of the loans portfolio (LOANS) and the efficiency of Latin American banks.

The variable EQUITY RATIO measures banks equity ratio adequacy. Theory states that high levels of EQUITY RATIO leads to higher efficiency. Casu and Molineux (2002) argue that lower EQUITY RATIO levels imply a higher risk-taking propensity and greater leverage, which could result in greater borrowing costs. Thus, a positive relation between EQUITY RATIO and the efficiency of Latin American banks is expected.

Theory also predicts that large well-diversified banks will be less likely to fail than small banks. Bank size serves as a proxy for a bank's ability to diversify since large banks have better diversified asset portfolios (Shyu and Reichert, 2002; Mester, 1993). Thus, a positive relation between the efficiency scores of Latin American banks and bank size as measured by the variable TOTAL ASSETS is expected. 
Since equation (2) will be estimated using the efficiency scores from the three Latin American countries in a pooled model, the variable ECON FREE is included to control for economic and regulatory differences between the three countries. ECON FREE is the economic freedom index that the Heritage Foundation calculates on a yearly basis. The index represents an average of 10 individual factors that allows one to classify countries as free, mostly free, mostly unfree, or repressed. ${ }^{3}$ According to this index, Brazil and Mexico are classified as "mostly unfree" while Chile is classified as "mostly free." Thus, ECON FREE is defined as a dummy variable that takes a value of 1 if the country is "mostly unfree" (Brazil and Mexico) or 0 if it is mostly free (Chile).

\section{DATA AND SUMMARY STATISTICS}

The data used in this study were obtained from three different sources: the Bankscope database (2001), the Heritage Foundation webpage, and information published by the Central Bank of each Latin American country. These data sources contained the income statement and balance sheet of state, private, and foreign banks operating in Latin America. We examined the financial statements in order to identify banks which contained information regarding derivatives usage. The result of this extensive and detailed examination indicated that only the banks from Brazil, Chile, and Mexico contained information relating to derivatives usage. As such, the analysis is limited to these three Latin American countries. After eliminating banks with missing values, the final data set consisted of 116 Brazilian banks, 27 Chilean banks, and 39 Mexican banks.

We obtained the data for the variable DERIVATIVES for Brazil and Mexico from Bankscope (2001) and for Chile we obtained it from data published by the Superintendencia de Bancos e Instituciones Financieras de Chile (2002). The variable DERIVATIVES comes from the total notional value of derivatives used by each bank. Because of the highly aggregate nature of the variable DERIVATIVES it was not possible to identify the type of derivatives (e.g. swaps, options, forward) being used by the banks.

The financial statements containing the data used for the VRS-DEA model (TOTAL INCOME, TOTAL DEPOSITS, and TOTAL NONINTEREST EXPENSES) as well as the variables used in the OLS regression (LOANS, EQUITY RATIO, and TOTAL ASSETS) were obtained from the Bankscope database and information published by the Central Bank of Brazil, Chile, and Mexico. Finally, the ECON FREDOM data was obtained from the Heritage Foundation webpage.

Table 1 presents the average efficiency scores by country and by derivatives user and non-user banks. On average, derivatives user banks have a greater efficiency scores than non-user banks in the three countries. Note also that on average Chilean banks have the highest efficiency mean score followed by Brazilian banks and then Mexican banks. There was also no evidence that the efficiency scores tended to be clustered at the upper (1) or lower (0) levels.

The Mann-Whitney and Kruskal Wallis tests, and a one-way ANOVA were employed to examine the mean efficiency score differences between derivatives user banks and non-user banks. The null hypothesis for these tests was that there is no difference between the efficiency score of derivatives user banks and non-user banks. All the test results (see Table 1) failed to reject the null hypothesis, implying that there is no significant difference between the efficiency scores of the derivatives user banks and non-user banks. However, these tests are only indicative since they do not control for other factors that can influence the efficiency of banks.

\footnotetext{
${ }^{3}$ The 10 factors include trade policy, government intervention, foreign investment, wages and prices, regulation, fiscal burden, monetary policy, banking and finance, property rights, and black market. Using only the banking and finance sector does not significantly change the results. Therefore, the variable ECON FREE is used since it is more inclusive of other factors that could indirectly affect the banking sector.
} 
Table 1: Average Efficiency Scores Per Country And In The Aggregate

\begin{tabular}{lcccc}
\hline & Brazil & Chile & Mexico & Pooled Scores \\
\hline Non-user & 0.764 & 0.979 & 0.537 & 0.728 \\
User & 0.803 & 0.928 & 0.621 & 0.787 \\
Total & 0.791 & 0.936 & 0.596 & 0.770 \\
Mann-Whitney test & -0.934 & 0.300 & -1.128 & -1.361 \\
& $(0.350)$ & $(0.764)$ & $0.259)$ & $(0.174)$ \\
Kruskal-Wallis test & 0.873 & 0.090 & $(0.259)$ & 1.852 \\
& $(0.350)$ & $(0.764)$ & 0.229 & $(0.174)$ \\
ANOVA & 0.776 & 4.393 & $(0.632)$ & 1.685 \\
& $(0.378)$ & $(0.036)$ & & $(0.194)$ \\
\hline
\end{tabular}

Note. P-values in parentheses.

Table 2 provides a comparison between banks that use derivatives and those that do not use derivatives within Brazil, Chile, Mexico and the pooled data. Panel A presents the comparison for the pooled sample. Note that the five variables have differences in means that are statistically significant. On average derivatives user banks are about two times larger than nonusers banks, and have more LIQUIDITY, larger LOANS and greater TOTAL ASSETS compared to nonuser banks. However, the pooled sample shows that user banks have lower EQUITY RATIO compared to nonuser banks.

Panel B in Table 2 presents the comparisons for Brazilian banks. For the Brazilian banks, note that the results present similar pattern to the pooled data in which all the five variables have statistically significant differences in means. This suggest that Brazilian user banks on average are about two times larger than nonusers banks, and on average have more LIQUIDITY, larger LOANS and greater TOTAL ASSETS compared to nonuser banks. However, Brazilian user banks have lower EQUITY RATIO compared to Brazilian nonuser banks.

Panel $\mathrm{C}$ in Table 2 presents the comparisons for Chilean banks. For the Chilean banks, four of the five variables have statistically significant differences in means. This suggest that Chilean user banks on average are about 10 times larger than nonusers banks. Additionally, derivative user banks on average have more LIQUIDITY and larger TOTAL ASSETS compared to Chilean nonuser banks. However, Chilean user banks have lower EQUITY RATIO compared to Chilean nonuser banks. Lastly, the variable LOAN is not statistically different amongst derivatives user and nonuser Chilean banks.

Panel D in Table 3 presents the comparisons for Mexican banks. The differences in means between derivatives user and nonuser Mexican banks are statistically significant for all the five variables. This suggest that Mexican derivative user banks are about 7 times larger than nonuser banks, have on average greater LIQUIDITY, LOANS, and TOTAL EQUITY but lower EQUITY RATIO compared to Mexican nonuser banks.

\section{EMPIRICAL RESULTS}

The result of the OLS estimation of equation (2) is presented in Table 3. Four models were estimated: one for each country. Each estimated model was checked for the presence of heteroskedasticity using the Cook and Weisberg test and in each case, there was no need to correct for heteroskedasticity. ${ }^{4}$ However, for the pooled-data model, there was statistical evidence regarding the presence of heteroskedasticity. As a result this model was estimated using robust standard errors (Greene, 2003).

\footnotetext{
${ }^{4}$ In the literature, various studies (Isik and Hassan 2002) have used OLS to estimate equation (2). However, it is recognized in the literature that the efficiency scores range from zero (least inefficient) to one (most efficient) and that in some cases the scores tend to cluster (or be censored) around zero and/or one. As a result, some studies use a Tobit model to account for this censoring effect (Casu and Molineux, 2002; McAllister and McManus, 1993). Since the data for the present study do not show signs of censoring, we do not use a Tobit estimator but instead use the OLS estimator.
} 
Table2: Differences In Means For Brazilian, Chilean, And Mexican Banks: Derivatives Users Vs. Nonusers

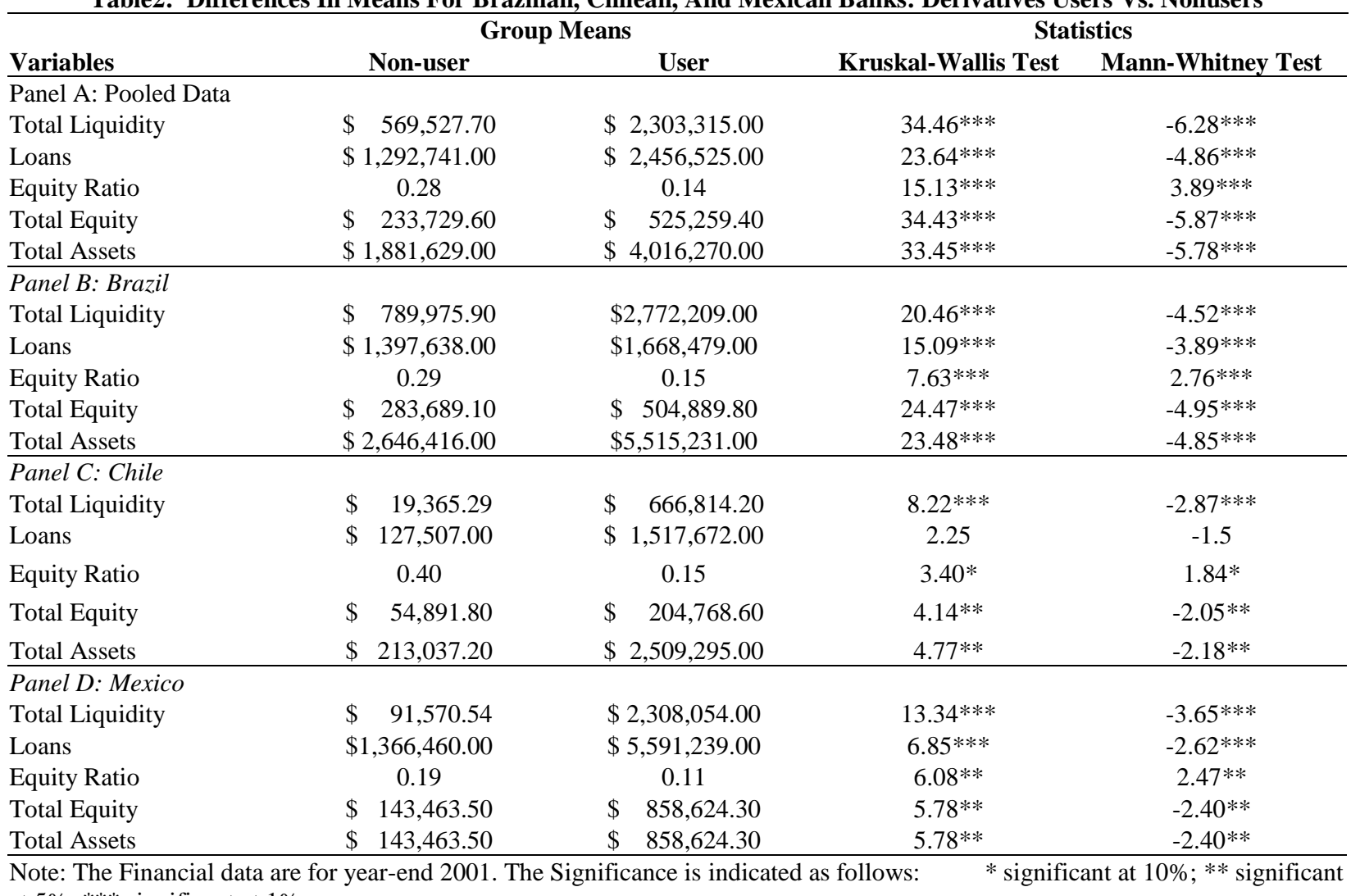
at $5 \%$; *** significant at $1 \%$

It is readily obvious in Table 3 that the per country estimated regressions are very poor. For the case of Brazil and Mexico, only the coefficient for the variable EQUITY RATIO is significant. For the case of Chile, none of the estimated coefficients are significant and the estimated sign of the variable LOANS is incorrect. Thus, the results of the three per country regression estimates were discarded.

Alternatively, the estimated pooled model is a much more appropriate model compared to the per country estimated models. In the pooled model, all the coefficients have the expected sign and are significant. The $\mathrm{R}^{2}$ is low as expected for cross-sectional data.

As can be observed in Table 3, the estimated coefficient of our variable of interest, DERIVATIVE, is positive and significant. This indicates that the use of derivatives increases the efficiency of Brazilian, Chilean, and Mexican banks. This result is consistent with the argument that the use of derivatives can improve the bank's efficiency by reducing the explicit cost of financial distress and the probability of bankruptcy (Merton, 1995; Mayers and Smith, 1982; Smith and Stulz, 1985).

The results for the control variables in Table 3 are consistent with previous studies of determinants of efficiency. Regarding the estimated coefficient for the variable LOANS is positive and significant. This result implies that as the level of portfolio LOANS increases the efficiency of Latin American banks increases. Banks with greater levels of portfolio LOANS can maintain their levels of equity ratio and perform at higher levels of efficiencies (McAllister and McManus, 1993). 
Table3: OLS Regression Results On Efficiency Scores

\begin{tabular}{|c|c|c|c|c|}
\hline & $\begin{array}{c}(1) \\
\text { Brazil }\end{array}$ & $\begin{array}{c}\text { (2) } \\
\text { Chile }\end{array}$ & $\begin{array}{c}(3) \\
\text { Mexico }\end{array}$ & $\begin{array}{c}(4) \\
\text { Pooled Model }^{\mathrm{a}} \\
\end{array}$ \\
\hline Constant & $\begin{array}{c}0.693 * * * \\
(0.000)\end{array}$ & $\begin{array}{c}0.966 * * * \\
(0.000)\end{array}$ & $\begin{array}{c}0.381 * * * \\
(0.000)\end{array}$ & $\begin{array}{c}0.818^{* * * *} \\
(0.000)\end{array}$ \\
\hline Loans & $\begin{array}{c}0.002 \\
(0.776)\end{array}$ & $\begin{array}{l}-0.006 \\
(0.956)\end{array}$ & $\begin{array}{c}0.021 \\
(0.437)\end{array}$ & $\begin{array}{c}0.008 * * \\
(0.020)\end{array}$ \\
\hline Equity Ratio & $\begin{array}{c}0.190 * * \\
(0.034)\end{array}$ & $\begin{array}{c}0.024 \\
(0.857)\end{array}$ & $\begin{array}{l}0.652^{*} \\
(0.096)\end{array}$ & $\begin{array}{c}0.268 * * * \\
(0.002)\end{array}$ \\
\hline Total Assets & $\begin{array}{c}0.005 \\
(0.101)\end{array}$ & $\begin{array}{c}0.018 \\
(0.781)\end{array}$ & $\begin{array}{c}0.001 \\
(0.926)\end{array}$ & $\begin{array}{c}0.005^{* *} \\
(0.015)\end{array}$ \\
\hline Derivatives & $\begin{array}{c}0.050 \\
(0.144)\end{array}$ & $\begin{array}{l}-0.077 \\
(0.285)\end{array}$ & $\begin{array}{c}0.034 \\
(0.668)\end{array}$ & $\begin{array}{l}0.055^{*} \\
(0.094)\end{array}$ \\
\hline Econ Free & & & & $\begin{array}{c}-0.199 * * * \\
(0.000)\end{array}$ \\
\hline Cook-Weisberg test & $\begin{array}{c}0.910 \\
(0.341)\end{array}$ & $\begin{array}{c}9.050 \\
(0.012)\end{array}$ & $\begin{array}{c}0.150 \\
(0.703)\end{array}$ & \\
\hline R-squared & 0.146 & 0.127 & 0.441 & 0.254 \\
\hline Observations & 116 & 27 & 39 & 182 \\
\hline
\end{tabular}

Note: ${ }^{a}$ Pooled model regression with robust standard errors. P-values in parentheses. Significance is indicated as follows:

* significant at $10 \%$; ** significant at $5 \%$; *** significant at $1 \%$

The estimated coefficient for EQUITY RATIO in the pooled model is positive and significant suggesting that as Latin American banks increases their EQUITY RATIO their efficiency increases. Higher EQUITY RATIO levels implies lower risk-taking propensity, lower leverage resulting in lower borrowing cost.

The estimated coefficient for TOTAL ASSETS is positive and significant for the pooled model as well. This implies that as Latin American banks get larger their efficiency level increases. This result supports the theory that large banks have better diversified asset portfolio and economies of scales thus becoming more efficient (Shyu and Reichert, 2002; Mester, 1993).

Lastly, the variable economic freedom (ECON FREE) is negative and significant. Recall that this variable was included to control for different regulatory and institutional constraints amongst Brazil, Chile, and Mexico. The results indicate that banks in Latin American countries which are mostly free (like Chile) are more efficient than banks in Latin American countries that are mostly unfree (such as Brazil and Mexico). This implies that regulatory and institutional constraints result in having a banking sector that is more inefficient as compare to bank with less regulatory, and institutional constraints.

\section{CONCLUSION}

In this paper, the issue of whether the use of derivatives affects the efficiency of Latin American banks is investigated. To address this issue, we employed a two-stage estimation approach. In the first stage, the efficiency scores of the banks from Brazil, Chile, and Mexico were calculated using an input-oriented, variable return to scale DEA model. In the second stage, the efficiency scores were regressed on a dummy derivatives variable as well as other variables that controlled for size, loans, EQUITY RATIO, and economic and regulatory constraints under which the banks operates.

Overall, the results indicate that the use of derivatives increases the efficiency of Latin American banks. This result is consistent with the argument that banks can use derivatives to improve their efficiency by reducing the explicit cost of financial distress and the probability of bankruptcy (Mayers and Smith, 1982; Smith and Stulz, 1985; Merton, 1995). The results also indicates that the size of portfolio loans, EQUITY RATIO levels and total assets have a statistically positive effect on the efficiency of Latin American banks. Lastly, the results show that regulatory and institutional constraints can negatively affect the efficiency of Latin American banks. 
Although the contributions of this study are significant and important to Latin American policy-makers, investors, and bank executives, they have to be interpreted with caution due to the limitation of the variable DERIVATIVES. In this study, it was not possible to distinguish between interest-rate and currency derivatives, nor distinguish between forwards, futures, swaps, and options, and this could have a bearing on our findings. Nevertheless, this is the first study to examine the issue of efficiency and the use of derivatives. Therefore, as Latin American banks reporting requirements becomes more detailed and standardized across countries, future studies should analyze the effect of derivatives on Latin American banks taking in consideration the difference between interest-rate derivatives and currency derivatives, and/or the different types of derivatives such as swaps, futures, forwards, and options.

\section{REFERENCES}

1. Banco Central do Brasil. Economic and financial information report for 2001 English version, (http://www.bcb.gov.br/).

2. Banco de Mexico. Informacion financiera y economica para el 2001, (http://www.banxico.org.mx).

3. Berger, A. N. and D. B. Humphrey, 1997. Efficiency of financial institutions: international survey and directions for future research. European Journal of Operational Research 98, 175-212.

4. Berger, A. N. and D.B Humphrey, 1992. Measurement and efficiency issues in commercial banking, output measurement in the service sector. University of Chicago Press 7, 245-279.

5. Berger, A.N., W. Hunter, and S. Timme, 1993. The efficiencies of financial institutions: A review and preview of research past present and future. Journal of Banking and Finance 17, 21-249.

6. Brewer, E., III, W.E. Jackson, and J.T. Moser, 1997. Alligators in the swamp: the impact of derivatives on the financial performance of depositary institutions. Journal of Money, Credit, and Banking 28, 482-497.

7. Canhoto, A. and J. Dermine, 2003. A note on banking efficiency in Portugal: New vs. Old banks. Journal of Banking and Finance 27, 2087-2098.

8. Carter, D. A. and J.F. Jr. Sinkey, 1998. The use of interest-rate derivatives by end users: the case of large community banks. Journal of Financial Services Research 14, 17-34.

9. Casu, B. and P. Molyneux, 2002. A comparative studies of efficiency in European banking. Working paper.

10. Chaudhry, M. and A. Reichert, 1999. The impact of off-balance sheet derivatives and interest rate swaps on bank risk. Research in Finance 17, 275-300.

11. Chaudhry, M.K., R. Christie-David, R., T.W. Koch, and A.K. Reichert, 2000. The risk of foreign currency contingent claims at us commercial banks. Journal of Banking and Finance 24, 1399-1417.

12. Choi, J., Elyasiani, E., 1997. Derivative exposure and the interest rate and exchange rate risks of U.S. banks. Journal of Financial Services Research 12, 267-286.

13. Clark, J., 1988. The economies of scale and scope at depository financial institutions: A review of the literature. Economic Review, Federal Reserve Bank of Kansas City, 16-33.

14. Coelli, T., D.S.P. Rao, and G.E. Battese, 1998. An Introduction to Efficiency and Productivity Analysis. Boston, Dordrecht, London: Kluwer Academic Publishers.

15. Elyasiani, E. and Mehdian, S., 1995. The comparative efficiency performance of small and large US commercial banks in the pre- and post-deregulation eras. Applied Economics 27, 1069-1079.

16. Favero, C. A. and L. Papi, 1995. Technical efficiency and scale efficiency in the italian banking sector: a non-parametric approach. Applied Economics 27, 385-395.

17. Fischer K.P., Gueyie, J.P., \& Ortiz, E. (1997). Financial liberalization: commercial bank's blessing or curse? Retrieved February 2002 from the February Centre de Recherche en Economie et finance Apliquées (CRÉFA) working paper database.

18. Fok, Robert C. W., Carroll, C., and Chiou, M. C., 1997. Determinants of Corporate Hedging and Derivatives: A Revisit. Journal of Economics and Business pp. 569-585

19. Froot, K.A. Scharfstein, D.S., and Stein, J.C. (1993): Risk Management: Coordinating Corporate Investment and Financing Policies, Journal of Finance 48, December 1993, pp. 1629-1658.

20. Gunther, J.W. and T.F. Siems, 1995. Who's capitalizing on derivatives? Financial Industries Studies. Federal Reserve Bank of Dallas. July, 1-8.

21. Gunther, J.W. and T.F. Siems, 1996. The likelihood and extent of bank participation in derivatives activities. Financial Industries Studies, Federal Reserve Bank of Dallas Working Paper. 
22. Heritage Foundation. Index of Economic Freedom web page for the year 2001 (http://www.heritage.org)

23. Hirtle, B., 1997. Derivatives, portfolio composition, and bank holding company interest rate risk exposure. Journal of Financial Services Research 12, 243-266.

24. Hughes, J.E. and McDonald, S.B. (2002). International Banking, Addison Wesley, New York, NY.

25. Isik, I. and M. K. Hassan, 2002. Technical, scale and allocative efficiencies of turkish banking industry. Journal of Banking and Finance 26, 719-766.

26. Mayers, D. and C.W. Smith, 1982. On the corporate demand for insurance. Journal of Business 55, 281-296.

27. McAllister, P.H., and D. McManus, 1993. Resolving the scale efficiency puzzle in banking. Journal of Banking and Finance 17, 389-405.

28. Merton, R., 1992. Financial innovation and economic performance. Journal of Applied Corporate Finance 4, $12-22$.

29. Merton, R., 1995. Financial innovation and the management and regulation of financial institutions. Journal of Banking and Finance 19, 461-481.

30. Mester, L., 1993. Efficiency in the saving and loan industry. Journal of Banking and Finance 17, 267-286.

31. Reichert, A. and Y. Shyu, 2003. Derivative activities and the risk of international banks: a market index and $\mathrm{VaR}$ approach. International Review of Financial Analysis 12, 489-511.

32. Rivas, A.E. and T. Ozuna, 2003. Characterizing the Use of Derivatives by Latin American Banks. Working Paper UTPA, Department of Economics and Finance

33. Shanker, L., 1996. Derivative usage and interest rate risk of large banking firms. The Journal of Future Markets 16, 459-474.

34. Shyu Y. and A. Reichert, 2002. The determinants of derivative and use by US and foreign banks. Research in Finance 19, 143-172.

35. Sinkey, J.F., Jr. and D.A. Carter, 2000. Evidence on the financial characteristics of banks that do and do not use derivatives. The Quarterly Review of Economics and Finance 40, 431-449.

36. Smith, C. and R. Stulz, 1985. The Determinants of firms' hedging policies. The Journal of Financial and Quantitative Analysis 20, 391-405.

37. Superintendencia de Bancos e Instituciones Financieras Chile. Información Financiera Estados Financieros Anuales Bancos y Sociedades Financieras Diciembre de 2002, (http://www.sbif.cl/cgi-bin/financiera.pl).

38. Taylor, W. M., R.G. Thompson, R.M. Thrall, and P.S. Dharmapala, 1997. DEA/AR efficiency and profitability of Mexican banks a total income model. European Journal of Operational Research 98, 346363.

39. Whidbee, D.A. and M. Wohar, 1999. Derivative activities and managerial incentives in the banking industry. Journal of Corporate Finance 5, 251-276. 